FACTA UNIVERSITATIS

Series: Economics and Organization Vol. 18, № 2, 2021, pp. 103 - 116

https://doi.org/10.22190/FUEO210110009K

Original Scientific Paper

\title{
MILLENNIALS IN THE CREATION OF SOCIAL VALUE OF THE ENTERPRISE
}

\author{
$U D C 005.35$
}

\begin{abstract}
Anna Kramarenko
V.N. Karazin Kharkiv National University, Educational and Scientific Institute "Karazin Business School", Department of Management and Administration, Ukraine

Abstract. The article emphasizes the creative activity that underlies the concept of "social value", which forms in the course of solving actual social problems. Social responsibility is mainly determined by reducing the negative impact of business on the basis of support and development of innovative projects. An analytical comparison of the categories of "social value" and "social responsibility" with the Sustainable Development Goals revealed a greater correspondence of the concept of "social value" to the sustainable development strategy. A statistical study of data from European countries allowed to draw a conclusion about the increase in social value in consumption, recycling of production resources, the use of renewable energy sources, and the growth of preferences for the development of own business. Based on the conducted research, the article highlights the exceptional role of millennials in updating the issues of social focus of business.
\end{abstract}

Key words: social responsibility, social value, sustainable development strategy, Gen Y.

JEL Classification: M140

\section{INTRODUCTION}

In Deloitte's 2019 Global Human Capital Trends Report, 44\% of business and HR executives surveyed said social entrepreneurship issues are more important to their organizations than they were three years ago, and $56 \%$ expect them to become even more important in three years (Deloitte, 2020). In Deloitte's 2019 Global Cxos survey, 73\% said their organizations had changed or developed products or services in the past year to make a positive impact on society (Deloitte, 2020).

Received January 10, 2021 / Revised January 22, 2021 / Revised March 07, 2021 / Accepted March 14, 2021 Corresponding author: Anna Kramarenko

V.N. Karazin Kharkiv National University, Educational and Scientific Institute "Karazin Business School", Department of Management and Administration, Kharkiv, Ukraine

E-mail: a.o.kramarenko@karazin.ua 
The research results show the increasing relevance of the issues of social influence of business. If we consider the impact of the activities of enterprises on society, it is worth paying special attention to the study of the essence of the concepts of "social responsibility" and "social value".

Questions of social focus of business are interesting not only for entrepreneurs, but also for scientists. For example, recent research has identified a U-shaped relationship between an entrepreneur's age and their willingness to create social value (Brieger et al, 2020). According to the researchers, the emphasis on creating social values decreases with increasing age throughout early middle age, during which entrepreneurs are more likely to prioritize personal values. However, the age factor can be considered as one of the determinants motivating the creation of social value. Thus, a more detailed study of the social identity of the main stakeholders of the social orientation of business is of scientific interest.

As part of the study, a literature review of publications related to the social identity of millennial, the concepts of "social responsibility" and "social value" was conducted. Based on the literature review, scientific hypotheses were put forward, the verification of which was described in the results. At the end of the study, the conclusions obtained as a result of studying the problems of social orientation of business are presented.

\section{LITERATURE REVIEW AND HYPOTHESIS DEVELOPMENT}

Recent studies demonstrate that individuals enjoy the pursuit of specific brands to express their sense of belonging to a social group or status (Helal \& Ozuem, 2019; Aaker, 2004; Adjei et al, 2009; Algesheimer et al, 2005, Tsimonis \& Dimitriadis, 2014). The point of discussion is the direction of mutual influence of brand demand and belonging to a social group (Brickson, 2007; Gielnik et al, 2012; Kanfer \& Ackerman, 2004; Kautonen et al, 2011). Perhaps it is belonging to a social group that determines the demand for specific brands. Researchers claim that millennial influence should be reflected in organizations' strategic plans, brand messaging, and stakeholder networks (Maiers, 2017; Acs et al, 2013; Athayde, 2009). Agreeing with this statement, we note that it is worth delving into the advantages of such a strategy. The influence of Gen $\mathrm{Z}$ is expanding, but what is the social influence of representatives of this generation (Francis \& Hoefel, 2020).

Recent studies point different features of millennials, such as thinking complexly (Afifah, 2020), extraordinary thinking abilities (Yusri, 2020), idealistic, altruistic generation (Gay, 2017), collaborative, accessible, responsible (Haber, 2016), looking for employers with CSR values (PwC, 2020), impacted by internet influencers (Loeb, 2020). At the same time, it is advisable to systematize scientific developments in order to more fully reveal the social influence of Generation Y.

Recent research shows dramatic shifts in youth behaviors, attitudes and lifestyles (Dimock, 2019). It is the issue whether entrepreneurs' individual resources influence their willingness to create social value and to meet principles of sustainable development (Brieger\& De Clercq, 2019; Carsrud \& Brännback, 2011; Cohen et al, 2008; Hörisch et al, 2017; Hörisch et al, 2019; Kautonen et al, 2014; Wiernik et al, 2013) and what are the causes of social tensions inside the countries (Gontareva et al, 2021; De Clercq et al, 2013; Estrin et al, 2013; Estrin et al, 2016). 
Thus, we summarized our thoughts in the following hypotheses:

Hypothesis 1: "Social value" in a conceptual comparison with the concept of "social responsibility", which previously was the base for progressive corporate strategies, demonstrates greater compliance with the current principles of sustainable development.

Hypothesis 2: The most motivated actors in creating social value for businesses are Gen Y (millennials) social and entrepreneurial identities.

The purpose of the research is to test hypotheses theoretically and practically, to define the social aspects of entrepreneurship, to determine the correspondence of the social and environmental principles of modern business, to identify the key actors in the formation and promotion of the social value of entrepreneurship.

To achieve the goal of the study, comparison, generalization, analysis, synthesis, deduction, induction, as well as statistical analysis were used.

\section{RESULTS}

First, the existing approaches to determining the social responsibility of the enterprise were studied. The main definitions of the categories "social responsibility" and "social value" are presented in Tables 1 and 2 accordingly.

Table 1 Definition of the category "social responsibility"

\begin{tabular}{ll}
\hline Source & Definition \\
\hline Investopedia & $\begin{array}{l}\text { "Social responsibility means that a business, in addition to maximizing } \\
\text { shareholder value, must act in a way that benefits society. However, } \\
\text { critics argue that the basic nature of business does not view society as an } \\
\text { interested party" (Ganty, 2020). }\end{array}$ \\
American Society for Q & $\begin{array}{l}\text { "Social responsibility is a means to achieve sustainability. Adopting key } \\
\text { principles of social responsibility, such as accountability and } \\
\text { uality (ASQ) }\end{array}$ \\
$\begin{array}{l}\text { transparency, can help ensure the long-term viability and success of any } \\
\text { organization or system" (American Society for Quality, 2020). }\end{array}$ \\
$\begin{array}{l}\text { "Corporate social responsibility is a management concept in which } \\
\text { Industrial Development } \\
\text { Organisation (UNIDO) }\end{array}$ & $\begin{array}{l}\text { companies integrate social and environmental concerns into their } \\
\text { business operations and interactions with their stakeholders" (United } \\
\text { Nations Industrial Development Organisation, 2020). }\end{array}$ \\
Business News Daily & $\begin{array}{l}\text { "Corporate social responsibility (CSR) is a type of self - regulation of a } \\
\text { business to ensure social responsibility; many corporate CSR initiatives } \\
\text { seek to make a positive contribution to society, the economy, or the } \\
\text { environment" (Schooley, 2020) }\end{array}$
\end{tabular}

Source: built by author based on Ganty, 2020, American Society for Quality, 2020, United Nations Industrial Development Organisation, 2020, Schooley, 2020 
Table 2 Definition of the category "social value"

\begin{tabular}{|c|c|}
\hline Organization & Definition \\
\hline Bristol City Council & $\begin{array}{l}\text { "Social value is about maximizing the impact of public } \\
\text { expenditure to get the best possible outcomes, and } \\
\text { recognizing that local people are central to determining } \\
\text { how these can be achieved". }\end{array}$ \\
\hline BusinessDictionary.com & $\begin{array}{l}\text { "Social value is larger concept which includes social } \\
\text { capital as well as the subjective aspects of the citizens" } \\
\text { well-being, such as their ability to participate in making } \\
\text { decisions that affect them". }\end{array}$ \\
\hline Kirklees Council & $\begin{array}{l}\text { "If } £ 1 \text { is spent on delivery of services, can that same } £ 1 \text { be } \\
\text { used to also produce a wider benefit to the community?" }\end{array}$ \\
\hline $\begin{array}{l}\text { National Association of Certified } \\
\text { Valuation Analysts (NACVA) }\end{array}$ & $\begin{array}{l}\text { "Social value is about maximizing the impact of public } \\
\text { expenditure. It looks at what is created, and sometimes } \\
\text { what is forsaken, through a commissioning process". }\end{array}$ \\
\hline Social Value Hub & $\begin{array}{l}\text { "Social value is the benefit to the community from a } \\
\text { commissioning/procurement process over and above the } \\
\text { direct purchasing of goods, services and outcomes". }\end{array}$ \\
\hline $\begin{array}{l}\text { Sustainable Procurement Task Force } \\
2006\end{array}$ & $\begin{array}{l}\text { "Social value is a process whereby organizations meet their } \\
\text { needs for goods, services, works and utilities in a way that } \\
\text { achieves value for money on a whole life basis in terms of } \\
\text { generating benefits to society and the economy, whilst } \\
\text { minimizing damage to the environment". }\end{array}$ \\
\hline $\begin{array}{l}\text { The Public Services (Social Value) Act } \\
2012\end{array}$ & $\begin{array}{l}\text { "Social value seeks to maximize the additional benefit } \\
\text { that can be created by procuring or commissioning } \\
\text { services, above and beyond the benefit of merely the } \\
\text { services themselves". }\end{array}$ \\
\hline
\end{tabular}

Source: UK Green Building Council, 2018

Based on tables 1 and 2, the categories "social responsibility" and "social value" were compared according to the criteria of key areas of activity, areas of influence and stakeholders. The results are presented in table 3.

Table 3 Comparison of the categories "social responsibility" and "social value"

\begin{tabular}{lll}
\hline Comparison criteria & Social responsibility & Social value \\
\hline Key areas of activity & $\begin{array}{l}\text { Innovative technologies } \\
\text { Green energy }\end{array}$ & Solving urgent social problems \\
Key impact & $\begin{array}{l}\text { Harm reduction, correction of } \\
\text { influence }\end{array}$ & Creating positive external effects \\
Key actors & $\begin{array}{l}\text { Medium and large businesses, } \\
\text { global corporations } \\
\text { Government, business }\end{array}$ & $\begin{array}{l}\text { Microenterprises } \\
\text { Stakeholders }\end{array}$ \\
\end{tabular}

Source: built by author based on Hopkins, 2006

Further research is aimed at studying the correspondence of the concept of "social responsibility" and "social value" to the main goals of sustainable development. "The World Commission on Environment and Development (the Brundtland Commission) in its report to 
the United Nations in 1987 defined sustainable development as meeting the needs of the present without compromising the ability of future generation to meet their own needs" (United Nations, 2020). Thus, the principles of sustainable development determine the future of social development, the future of business. The desire of entrepreneurs to coordinate business activities is due not only to economic benefits, but also to the motivation to create a social effect. The formation of an entrepreneurial strategy is based on clear performance criteria. In this regard, it was studied to what extent the concepts of "social responsibility" and "social value" correspond to the goals of sustainable development. Agenda 21, adopted during the United Nations Conference on Environment and Development (UNCED) called Earth Summit held in Rio de Janeiro in Brazil in 1992 is a blue print on how to make development socially, economically and environmentally sustainable (United Nations, 2020).

The results of the study of the degree of influence of social orientations on the achievement of the Sustainable Development Goals are presented in table 4.

Table 4 Compliance of the concepts of "social responsibility" and "social value" with the Sustainable Development Goals

\begin{tabular}{|c|c|c|}
\hline $\begin{array}{l}\text { Sustainable Development Goals } \\
\text { (United Nations) }\end{array}$ & "Social responsibility" & "Social value" \\
\hline $\begin{array}{l}\text { Goal 1: } \\
\text { No poverty }\end{array}$ & & $\begin{array}{l}\text { Enterprises that create social } \\
\text { value are focused on involving } \\
\text { people with different income } \\
\text { levels in the creation of } \\
\text { marketable products }\end{array}$ \\
\hline $\begin{array}{l}\text { Goal 2: } \\
\text { Zero hunger }\end{array}$ & & $\begin{array}{l}\text { Manufacturing is focused on } \\
\text { creating the most sought-after } \\
\text { products, satisfaction is first and } \\
\text { foremost of the basic needs }\end{array}$ \\
\hline $\begin{array}{l}\text { Goal 3: } \\
\text { Good health and well-being }\end{array}$ & $\begin{array}{l}\text { Development and active } \\
\text { implementation of } \\
\text { comprehensive wellness } \\
\text { programs for the company's } \\
\text { employees }\end{array}$ & \\
\hline $\begin{array}{l}\text { Goal 4: } \\
\text { Quality education }\end{array}$ & $\begin{array}{l}\text { Corporations and the } \\
\text { government as stakeholders } \\
\text { and partners in the design } \\
\text { and creation of innovative } \\
\text { educational programs }\end{array}$ & \\
\hline $\begin{array}{l}\text { Goal 5: } \\
\text { Gender equality }\end{array}$ & $\begin{array}{l}\text { Equal gender opportunities } \\
\text { as part of corporate culture }\end{array}$ & $\begin{array}{l}\text { Women's employment as a } \\
\text { response to domestic violence, as } \\
\text { well as equal gender opportunities } \\
\text { for starting own business }\end{array}$ \\
\hline $\begin{array}{l}\text { Goal 6: } \\
\text { Clean water and sanitation }\end{array}$ & $\begin{array}{l}\text { Financing of environmental } \\
\text { projects }\end{array}$ & $\begin{array}{l}\text { Creating startups based on eco- } \\
\text { developments }\end{array}$ \\
\hline $\begin{array}{l}\text { Goal 7: } \\
\text { Affordable and clean energy }\end{array}$ & & $\begin{array}{l}\text { The implementation and } \\
\text { promotion of innovative } \\
\text { technological solutions based on } \\
\text { green energy }\end{array}$ \\
\hline
\end{tabular}




\begin{tabular}{lll}
\hline $\begin{array}{l}\text { Sustainable Development Goals } \\
\text { (United Nations) }\end{array}$ & "Social responsibility" & "Social value" \\
\hline $\begin{array}{l}\text { Goal 8: } \\
\begin{array}{l}\text { Decent work } \\
\text { and economic growth }\end{array}\end{array}$ & $\begin{array}{l}\text { Involvement of representatives of } \\
\text { various social groups in the } \\
\text { process of creating added value }\end{array}$ \\
$\begin{array}{ll}\text { Goal 9: } & \end{array}$ \\
$\begin{array}{l}\text { Industry, innovation, } \\
\text { and infrastructure }\end{array}$ & $\begin{array}{l}\text { Investment in the creation } \\
\text { and development of } \\
\text { infrastructure to scale the } \\
\text { business }\end{array}$ & \\
&
\end{tabular}

Goal 10:

Reduced inequalities

Goal 11:

Sustainable cities

and communities

Goal 12:

Responsible consumption and production

Goal 13:

Climate action

Goal 14:

Life below water

Goal 15:

Life on land

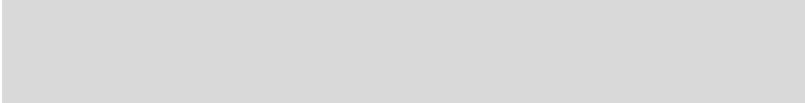

Goal 16:

Peace, justice and strong institutions

Goal 17:

Partnerships

Development of corporate ethics aimed at reducing the negative impact on the environment

Involvement of representatives of various social groups in the process of creating added value The implementation and promotion of innovative technological solutions based on green energy

Promotion of business ideas based on the principles of responsible consumption and production

Development of corporate Promotion of business ideas ethics aimed at reducing the based on the principles of negative impact on the environment responsible consumption and production

Implementation and promotion of technological business ideas based on elimination of pollution results and improvement of ecosystems

Implementation and promotion of technological business ideas based on elimination of pollution results and improvement of ecosystems

Creating prerequisites for "bottom-up management"

Active interaction with stakeholders in order to implement business ideas and scale them

Total number of compliance points 7 14

Source: built by author

Thus, the concept of social value is more consistent with the goals of sustainable development. An entrepreneurial approach based on the creation of social value is becoming more relevant. 
To test Hypothesis 2, we generalize the characteristics of millennials. Special attention is paid to the following issues:

- what products are most in demand by millennials (consumption characteristics);

- entrepreneurial activity of millennials (investment and creation of their own business);

- changing the standards of production activities (use of renewable energy and reuse of resources).

Based on the study of scientific materials devoted to the various socio-age groups of the population, the main information presented in Table 5 was systematized.

Table 5 Characteristics of social and age groups of the population

\begin{tabular}{lllll}
\hline & Baby Boomer & Gen X & \multicolumn{2}{l}{ Gen Y (millennial) Gen Z } \\
\hline \multirow{2}{*}{$\begin{array}{l}\text { Age in 2020 } \\
\text { Behavior basics }\end{array}$} & 1946-1964 & 1965-1980 & $1981-1996$ & $1997-2020$ \\
& Idealism & Materialistic & Globalist & Undefined ID \\
& Collectivist & Competitive & Questioning & Communaholic \\
& & Individualistic & Oriented to self & Dialoguer \\
& & & & Realistic \\
Consumption & Ideology & Status & Experience & Uniqueness \\
focus & Movies & Brands & Travel & Unlimited \\
& & Luxury & Flagships & Ethical \\
\hline
\end{tabular}

Source: built by author based on Fry \& Parker, 2018, Van Den Bergh et al., 2019

Summarizing the results of modern research, scientific publications and global surveys, it is possible to identify the main criteria for revealing the socio-economic identity of the millennial generation. These results are presented in table 6 below.

Table 6 Socio-economic identity Gen Y (millennial)

\begin{tabular}{ll}
\hline Parameter & Characteristics \\
\hline 1) Balance of personal and & - ability to think comprehensively, be creative, responsible and find \\
social values & solutions to surrounding problems; \\
- low assessment of the influence of leaders on society and the desire \\
of leaders to improve the world; \\
- the desire to travel and help society is greater (46\%) than the desire \\
to create families or own a business (34\%); \\
- among the 20 problems facing society, the most personal concerns are \\
about climate change and environmental protection. \\
- " $42 \%$ of millennials said they started or deepened business \\
relationships because the company's products or services have a \\
positive impact on society and / or the environment"; \\
- $37 \%$ of millennials said they ended or weakened business \\
relationships because of the company's ethical behavior; \\
- "36\% of millennials started / deepened relationships because they \\
believed the company was ethical"; \\
- millennials choose brands that actively voice social, cultural, \\
political and environmental motivation; they are even willing to \\
overpay for these brands.
\end{tabular}




\begin{tabular}{|c|c|}
\hline Parameter & Characteristics \\
\hline 3) Attitude to business & $\begin{array}{l}\text { " "millennials believe that businesses should prioritize the production of } \\
\text { high-quality goods and services ( } 36 \% \text { ) and job creation }(35 \%) \text { "; } \\
\text { - "the majority ( } 55 \%) \text { considers making a profit to be the main } \\
\text { achievement of the business"; } \\
\text { - according to millennials, business does not make enough efforts to } \\
\text { improve the skills of employees ( } 33 \% \text { said this is a priority; } 16 \% \\
\text { said it is being implemented), improve society ( } 32 \% \text { vs. } 16 \%) \text {, } \\
\text { improve and protect the environment ( } 27 \% \text { vs. } 12 \%) \text {; } \\
\text { - business ( } 30 \%) \text { is most responsible for training employees, followed } \\
\text { by educational institutions ( } 24 \%) \text {. }\end{array}$ \\
\hline 4) Entrepreneurial activity & $\begin{array}{l}\text { - striving for an open atmosphere of cooperation. Millennials believe in } \\
\text { themselves and their colleagues, because unlike previous generations, } \\
\text { Generation Y was raised in an atmosphere of equal relations and joint } \\
\text { decision-making; } \\
\text { - } 55 \% \text { of millennials are interested in starting their own business one day; } \\
\text { - } 63 \% \text { of millennials believe that the biggest obstacle to innovation is the } \\
\text { attitude of management. } \\
\text { - } 13 \% \text { of millennials surveyed said that their career goal includes } \\
\text { promotion. But } 67 \% \text { stated their goal to start their own business. }\end{array}$ \\
\hline $\begin{array}{l}\text { 5) A sense of social } \\
\text { responsibility }\end{array}$ & $\begin{array}{l}\text { - serious attitude to academic achievement (94\% of millennials believe } \\
\text { that higher education is necessary for success in life); } \\
\text { - the rate of violent crimes involving young people is at an all-time low. } \\
\text { Since } 1991 \text {, the number of teenage pregnancies has decreased by } 51 \% \text {. } \\
\text { The number of teenagers smoking has plummeted. Drug use has } \\
\text { declined. All this indicates a higher level of responsibility; } \\
\text { - a high level of environmental component of demand (the use of green } \\
\text { packaging promotes promotion among young consumers); } \\
\text { - a high degree of humanism and philanthropy (the average millennial } \\
\text { gives almost } \$ 600 \text { a year to charity). }\end{array}$ \\
\hline
\end{tabular}

Based on the table 6, it can be argued that Gen Y representatives are often personally concerned about social and environmental problems, and base their consumer choices on these assumptions. Millennials believe that business is responsible not only for the quality of products, but also for the educational, cultural and political components of public relations. In this regard, Gen $\mathrm{Y}$ is more motivated to create a business and is ready to take responsibility for the results of their business activities.

To test hypothesis 2, a statistical study of data from EU countries was also conducted on the example of France, Germany, Greece and Poland. Testing of hypothesis 2 was carried out in three directions:

1) Products most in demand by Gen $Y$ representatives (consumption characteristics). Within the framework of the direction, the level of social inclusion (risk of poverty), the dynamics of greenhouse gas emissions were studied. The study of these indicators makes it possible to determine how rational and socially responsible millennials are in their consumption, as well as how representatives of this social group align their consumer ambitions with social and environmental effects. 
2) Entrepreneurial activity of millennials. Within the framework of the direction, the level of investment of households and the dynamics of motivation to create their own business were studied. Based on the data of the Global Entrepreneurship Monitor, the indicator Entrepreneurship as a Good Career Choice Rate was studied (Fig. 5): "Percentage of 18-64 population who agree with the statement that in their country, most people consider starting a business as a desirable career choice" (Global Entrepreneurship Monitor, 2020). Regression analysis of these indicators makes it possible to draw a conclusion about the trends of responsibility for creating a public product, a healthy competitive environment.

3) Change in production standards. Within the framework of the direction, the degree of resource reuse and the level of renewable energy use were studied. The analysis of these indicators in connection with the dynamics of the composition of the social group of millennials makes it possible to assess the impact of Gen $\mathrm{Y}$ on the change in the priorities of production standards towards socialization and greening.

The indicators used in the study are consistent with the Sustainable Development Goals, such as no poverty, affordable and clean energy, decent work and economic growth, sustainable cities and communities, responsible consumption and production. It is these goals that correspond to the creation of social value.

The study was conducted using regression analysis methods based on statistical data Eurostat Database and Global Entrepreneurship Monitor in 2009-2019. Using regression analysis, hypotheses were tested regarding the presence of an "impact-result" relationship (linear dependence) between a number of the studied values. The main parameters of the studied models are:

1) $R$ - the multiple correlation coefficient.

2) $R^{2}$ - the coefficient of determination that characterizes the quality of the model (the higher the value of this parameter, the greater the proportion of values that characterize this model).

3 ) The coefficients $a$ and $b$, which are the parameters of the linear regression equation $Y=a+b^{*} X$, where:

$X$ - variable impact

$Y$ - resulting parameter.

The sign and value of the coefficients $a$ and $b$ help to estimate the direction of the connection between $Y$ and $X$, as well as the strength of this connection.

The results of the analysis are presented in the tables.

Table 7 Results of the regression analysis for Germany

\begin{tabular}{|c|c|c|c|c|c|}
\hline X (impact) & Y (result) & $R$ & $R^{2}$ & Coefficient $a$ & Coefficient $b$ \\
\hline $\begin{array}{l}\text { Gen Y (millennial) } \\
\text { population rate }\end{array}$ & $\begin{array}{l}\text { Population at risk of poverty or } \\
\text { social exclusion }\end{array}$ & 0.69 & 0.48 & 0.79 & -0.19 \\
\hline $\begin{array}{l}\text { Gen Y (millennial) } \\
\text { population rate }\end{array}$ & Greenhouse gas emissions & 0.75 & 0.56 & 100.18 & -1.12 \\
\hline $\begin{array}{l}\text { Gen Y (millennial) } \\
\text { population rate }\end{array}$ & $\begin{array}{l}\text { Household investment share of } \\
\text { GDP }\end{array}$ & 0.69 & 0.48 & 4.19 & 0.08 \\
\hline $\begin{array}{l}\text { Gen Y (millennial) } \\
\text { population rate }\end{array}$ & $\begin{array}{l}\text { Entrepreneurship as a Good } \\
\text { Career Choice Rate }\end{array}$ & 0.66 & 0.44 & 41.39 & 0.40 \\
\hline $\begin{array}{l}\text { Gen Y (millennial) } \\
\text { population rate }\end{array}$ & Circular material use rate & 0.88 & 0.77 & -2.53 & 0.59 \\
\hline $\begin{array}{l}\text { Gen Y (millennial) } \\
\text { population rate }\end{array}$ & $\begin{array}{l}\text { Share of renewable energy in } \\
\text { gross final energy consumption }\end{array}$ & 0.90 & 0.82 & -29.26 & 1.88 \\
\hline
\end{tabular}


Table 8 Results of the regression analysis for Greece

\begin{tabular}{|c|c|c|c|c|c|}
\hline $\mathrm{X}$ (impact) & Y (result) & $R$ & $R^{2}$ & Coefficient $a$ & Coefficient $b$ \\
\hline $\begin{array}{l}\text { Gen Y (millennial) } \\
\text { population rate }\end{array}$ & $\begin{array}{l}\text { Population at risk of poverty or } \\
\text { social exclusion }\end{array}$ & 0.67 & 0.45 & 27.43 & -1.33 \\
\hline $\begin{array}{l}\text { Gen Y (millennial) } \\
\text { population rate }\end{array}$ & Greenhouse gas emissions & 0.92 & 0.84 & 364.62 & -11.22 \\
\hline $\begin{array}{l}\text { Gen Y (millennial) } \\
\text { population rate }\end{array}$ & $\begin{array}{l}\text { Household investment share of } \\
\text { GDP }\end{array}$ & 0.84 & 0.72 & -55.65 & 2.20 \\
\hline $\begin{array}{l}\text { Gen Y (millennial) } \\
\text { population rate }\end{array}$ & $\begin{array}{l}\text { Entrepreneurship as a Good } \\
\text { Career Choice Rate }\end{array}$ & 0.76 & 0.58 & 35.10 & 1.41 \\
\hline $\begin{array}{l}\text { Gen Y (millennial) } \\
\text { population rate }\end{array}$ & Circular material use rate & 0.56 & 0.31 & -9.95 & 0.52 \\
\hline $\begin{array}{l}\text { Gen Y (millennial) } \\
\text { population rate }\end{array}$ & $\begin{array}{l}\text { Share of renewable energy in } \\
\text { gross final energy consumption }\end{array}$ & 0.89 & 0.79 & -61.51 & 3.23 \\
\hline
\end{tabular}

Source: built by author

Table 9 Results of the regression analysis for France

\begin{tabular}{|c|c|c|c|c|c|}
\hline $\mathrm{X}$ (impact) & Y (result) & $R$ & $R^{2}$ & Coefficient $a$ & Coefficient $b$ \\
\hline $\begin{array}{l}\text { Gen Y (millennial) } \\
\text { population rate }\end{array}$ & $\begin{array}{l}\text { Population at risk of poverty or } \\
\text { social exclusion }\end{array}$ & 0.76 & 0.58 & 46.66 & -1.17 \\
\hline $\begin{array}{l}\text { Gen Y (millennial) } \\
\text { population rate }\end{array}$ & Greenhouse gas emissions & 0.71 & 0.51 & 169.3 & -3.36 \\
\hline $\begin{array}{l}\text { Gen Y (millennial) } \\
\text { population rate }\end{array}$ & $\begin{array}{l}\text { Household investment share of } \\
\text { GDP }\end{array}$ & 0.71 & 0.51 & 0.82 & 0.16 \\
\hline $\begin{array}{l}\text { Gen Y (millennial) } \\
\text { population rate }\end{array}$ & $\begin{array}{l}\text { Entrepreneurship as a Good } \\
\text { Career Choice Rate }\end{array}$ & 0.67 & 0.45 & 4.57 & 2.23 \\
\hline $\begin{array}{l}\text { Gen Y (millennial) } \\
\text { population rate }\end{array}$ & Circular material use rate & 0.76 & 0.59 & -34.97 & 2.20 \\
\hline $\begin{array}{l}\text { Gen Y (millennial) } \\
\text { population rate }\end{array}$ & $\begin{array}{l}\text { Share of renewable energy in } \\
\text { gross final energy consumption }\end{array}$ & 0.76 & 0.59 & -50.15 & 2.67 \\
\hline
\end{tabular}

$$
\text { Source: built by author }
$$

Table 10 Results of the regression analysis for Poland

\begin{tabular}{llcccc}
\hline X (impact) & Y (result) & $R$ & $R^{2}$ & Coefficient $a$ & Coefficient $b$ \\
\hline $\begin{array}{l}\text { Gen Y (millennial) } \\
\text { population rate }\end{array}$ & $\begin{array}{l}\text { Population at risk of poverty or } \\
\text { social exclusion }\end{array}$ & 0.64 & 0.41 & 32.53 & -1.3 \\
$\begin{array}{l}\text { Gen Y (millennial) } \\
\text { population rate }\end{array}$ & Greenhouse gas emissions & 0.91 & 0.84 & 68.22 & -1.65 \\
$\begin{array}{l}\text { Gen Y (millennial) } \\
\text { population rate }\end{array}$ & $\begin{array}{l}\text { Household investment share of } \\
\text { GDP }\end{array}$ & 0.89 & 0.79 & 0.7 & 0.30 \\
$\begin{array}{l}\text { Gen Y (millennial) } \\
\text { population rate }\end{array}$ & $\begin{array}{l}\text { Entrepreneurship as a Good } \\
\text { Career Choice Rate }\end{array}$ & 0.67 & 0.46 & 1.69 & 2.57 \\
$\begin{array}{l}\text { Gen Y (millennial) } \\
\text { population rate }\end{array}$ & Circular material use rate & 0.74 & 0.55 & 7.41 & 0.25 \\
$\begin{array}{l}\text { Gen Y (millennial) } \\
\text { population rate }\end{array}$ & $\begin{array}{l}\text { Share of renewable energy in } \\
\text { gross final energy consumption }\end{array}$ & 0.79 & 0.62 & 4.19 & 0.25 \\
\hline \multicolumn{1}{c}{ Source built by author } \\
\end{tabular}


According to the results of the regression analysis, in European countries there is a strong relationship between the number of millennials and the studied indicators (a linear relationship is confirmed in at least $41 \%$ of cases). At the same time, the values of the coefficients $a$ indicate that the relationship between the number of Gen Y and the level of poverty, as well as the volume of greenhouse gas emissions, is reversed, i.e., with the growth of the number of millennial generation, these indicators tend to decrease. The relationship between the other indicators is direct, i.e. with the growth of the number of Gen Y, the level of household investment, motivation for entrepreneurial activity, circular use of resources, and the use of renewable energy increases.

The observed trends indicate an increase in not only consumer, but also entrepreneurial consciousness. This is reflected in the increasing orientation of business not only to reduce, but also to create a positive social impact (solving environmental problems, fighting poverty, helping vulnerable social groups). Given the growing share of Gen Y representatives in the population of countries, there is a high level of dependence between the social identity of Gen Y and the social orientation of entrepreneurship.

\section{CONCLUSION}

An in-depth study of the essence of the concepts of "social responsibility" and "social value", as well as their comparison based on the Sustainable Development Goals, allowed us to conclude that the orientation of modern business strategies to "social value" is more promising. It is the concept of "social value" that has an advantage over the concept of "social responsibility" according to such goals as no poverty, zero hunger, affordable and clean energy, decent work and economic growth, reduced inequalities, sustainable cities and communities, life below water, life on land, peace, justice and strong institutions, partnerships.

A review of the results of previous studies made it possible to formulate the main characteristics of the Gen Y, such as concern about social and environmental problems, belief in the responsibility of the business for the quality of products, as well as for the educational, cultural and political components of public relations, high level of motivation to create a business and to take responsibility for the results of their business activities.

The criteria formulated based on the obtained conclusions provided the basis for studying the role of the Gen $\mathrm{Y}$ in creating social value using regression analysis. The results of the analysis show that representatives of the millennial generation significantly determine the growth of social efficiency of business, namely, reducing the risk of social exclusion and the level of greenhouse gas emissions, as well as the growth of private investment and entrepreneurial activity, increasing the circular use of resources, and the use of renewable energy.

\section{REFERENCES}

Aaker, D. (2004). Leveraging the Corporate Brand. California Management Review, 46(3), 6-18. https://doi.org/10.1177/000812560404600301

Acs, Z. J., Boardman,M. C., \& McNeely, C. L. (2013). The social value of productive entrepreneurship. Small Business Economics, 40(3), 785-796. https://doi.org/10.1007/s11187-011-9396-6

Adjei, M., Noble, S., \& Noble, C. (2009). The influence of C2C communications in online brand communities on customer purchase behavior. Journal of the Academy of Marketing Science, 38(5), 634-653. https://doi.org/10.100711747-009-0178-5. 
Afifah, L. (2020). Digitalization on Studies by Millenials Researcher. KnE Social Sciences, 4 (12), 280-290. https://doi.org/10.18502/kss.v4i12.7604

Algesheimer, R., Dholakia, U., \& Herrmann, A. (2005). The Social Influence of Brand Community: Evidence from European Car Clubs. Journal of Marketing, 69(3), 19-34. https://doi.org/10.1509/jmkg.69.3.19.66363

American Society for Quality (2020). What is Social Responsibility?. Retrieved from: https://asq.org/qualityresources/social-responsibility Accessed on: 08 January 2021.

Athayde, R. (2009). Measuring enterprise potential in young people. Entrepreneurship Theory and Practice, 33(2), 481-500. https://doi.org/10.1111/j.1540-6520.2009.00300.x

Auliandri, T. A., Rohman, A., Rohman, F., \& Rofiq, A. (2018). Does green packaging matter as a business strategy? Exploring young consumers' consumption in an emerging market. Problems and Perspectives in Management, 16(2), 376-384. https://doi.org/10.21511/ppm.16(2).2018.34

Awaluddin, I., \& Hamid, W. (2019). Interaction of social identity, empathy and planned behavior theories to understand domestic product purchasing intention. Problems and Perspectives in Management, 17(1), 95102. https://doi.org/10.21511/ppm.17(1).2019.09

Brickson, S. L. (2007). Organizational identity orientation: the genesis of the role of the firm and distinct forms of social value. Academy of Management Review, 32(3), 864-888. https://doi.org/10.5465/amr.2007. 25275679

Brieger, S. A., \& De Clercq, D. (2019). Entrepreneurs' individual level resources and social value creation goals: the moderating role of cultural context. International Journal of Entrepreneurial Behavior \& Research, 25(2), 193-216. https://doi.org/10.1108/IJEBR-12-2017-0503

Brieger, S. A., Bäro, A., Criaco, G., \& Terjesen, S. A. (2021). Entrepreneurs' age, institutions, and social value creation goals: A multi-country study. Small Business Economics, 57, 425-453. https://doi.org/10.1007/ s11187-020-00317-Z

Carsrud, A., \& Brännback, M. (2011). Entrepreneurial motivations: what do we still need to know? Journal of Small Business Management, 49(1), 9-26. https://doi.org/10.1111/j.1540-627X.2010.00312.X

Cohen, B., Smith, B., \& Mitchell, R. (2008). Toward a sustainable conceptualization of dependent variables in entrepreneurship research. Business Strategy and the Environment, 17(2), 107-119. https://doi.org/10.1002/ bse. 505

De Clercq, D., Lim, D. S., \& Oh, C. H. (2013). Individual-level resources and new business activity: the contingent role of institutional context. Entrepreneurship Theory and Practice, 37(2), 303-330. https://doi.org/10.1111/j.1540-6520.2011.00470.x

Deloitte (2020), The Deloitte Global Millennial Survey 2019. Retrieved from: https://www2.deloitte.com/cn/en/ pages/about-deloitte/articles/2019-millennial-survey.html/, Accessed on: 08 January 2021.

Dimock, M. (2019). Defining generations: Where Millennials end and Generation Z begins, Retrieved from: https://www.pewresearch.org/fact-tank/2019/01/17/where-millennials-end-and-generation-z-begins/, Accessed on: 08 January 2021.

Estrin, S., Mickiewicz, T., \& Stephan, U. (2013). Entrepreneurship, social capital, and institutions: social and commercial entrepreneurship across nations. Entrepreneurship Theory and Practice, 37(3), 479-504. https://doi.org/10.1111/etap.12019

Estrin, S., Mickiewicz, T., \& Stephan, U. (2016). Human capital in social and commercial entrepreneurship. Journal of Business Venturing, 31(4), 449-467. https://doi.org/10.1016/j.jbusvent.2016.05.003

European Commission (2020). Eurostat - Database, Retrieved from: https://ec.europa.eu/eurostat/web/main/ data/database, Accessed on: 08 January 2021.

Francis, T., \& Hoefel, F. (2020). True Gen: Generation Z and its implications for companies, Retrieved from: https://www.mckinsey.com/industries/consumer-packaged-goods/our-insights/true-gen-generation-Z-andits-implications-for-companies, Accessed on: 08 January 2021.

Fry, R., \& Parker, K. (2018). Early Benchmarks Show 'Post-Millennials' on Track to Be Most Diverse, BestEducated Generation Yet, Retrieved from: https://www.pewsocialtrends.org/2018/11/15/early-benchmarksshow-post-millennials-on-track-to-be-most-diverse-best-educated-generation-yet/, Accessed on: 08 January 2021.

Ganty, A. (2020). Social Responsbility, Retrieved from: https://www.investopedia.com/terms/s/socialresponsibility.asp Accessed on: 08 January 2021.

Gay, W. (2017). Millennials Are Effecting Change With Social Responsibility, Retrieved from: https://www.forbes. com/sites/wesgay/2017/08/11/millennials-social-responsibility/?sh=39d70f8517d8, Accessed on: 08 January 2021.

Giarratana, M. S., \& Pasquini, M. (2019). Corporate Social Responsibility in the Eyes of Millennials, Retrieved from: https://www.ie.edu/insights/articles/corporate-social-responsibility-in-the-eyes-of-millennials/, Accessed on: 08 January 2021

Gielnik, M. M., Zacher, H., \& Frese, M. (2012). Focus on opportunities as a mediator of the relationship between business owners' age and venture growth. Journal of Business Venturing, 27(1), 127-142. https://doi.org/10.1016/j.jbusvent.2010.05.002 
Global Entrepreneurship Monitor (2020). Data, Retrieved from: https://www.gemconsortium.org/data, Accessed on: 08 January 2021.

Gontareva, I., Babenko, V., Shmatko, N., \& Pawliszczy, D. (2021). Correlation of Income Inequality and Entrepreneurial Activity. Journal of Optimization in Industrial Engineering, 14(1), 51-56. https://doi.org/ 10.22094/joie.2020.677815

Haber, J. (2016). 6 Traits That Make Millennials the Best Social Entrepreneurs, Retrieved from: https://www.entrepreneur.com/article/271971 Accessed on: 08 January 2021.

Helal, G., \& Ozuem W. (2019). Social Media and Social Identity in the Millennial Generation, Retrieved from: https://www.researchgate.net/publication/330463094 Accessed on: 08 January 2021

Hopkins, M. (2006). What is corporate social responsibility all about? Retrieved from: https://www.researchgate.net/publication/246912286_What_is_corporate_social_responsibility_all_about Accessed on: 08 January 2021.

Hörisch, J., Kollat, J., \& Brieger, S. A. (2017). What influences environmental entrepreneurship? A multilevel analysis of the determinants of entrepreneurs' environmental orientation. Small Business Economics, 48(1), 47-69. https://doi.org/10.1007/s11187-016-9765-2

Hörisch, J., Kollat, J., \& Brieger, S. A. (2019). Environmental orientation among nascent and established entrepreneurs: an empirical analysis of differences and their causes. International Journal of Entrepreneurial Venturing, 11(4), 373-893. https://doi.org/10.1504/IJEV.2019.101623

Kanfer, R., \& Ackerman, P. L. (2004). Aging, adult development, and work motivation. Academy of Management Review, 29(3), 440-458. https://doi.org/10.5465/AMR.2004.13670969

Kautonen, T., Down, S., \& Minniti, M. (2014). Ageing and entrepreneurial preferences. Small Business Economics, 42(3), 579-594. https://doi.org/10.1007/s11187-013-9489-5

Kautonen, T., Tornikoski, E. T., \& Kibler, E. (2011). Entrepreneurial intentions in the third age: the impact of perceived age norms. Small Business Economics, 37(2), 219-234. https://doi.org/10.1007/s11187-009-9238-y

Loeb, W. (2020). Social Media Plays A Big Role In How Millennials Shop, But So Do Stores, Retrieved from: https://www.forbes.com/sites/walterloeb/2020/01/21/why-millennials-shop-on-social-media-but-also-liketo-shop-in-stores/?sh=3977502a350c Accessed on: 08 January 2021.

Maiers, M. (2017). Our future in the hands of Millennials. J Can Chiropr Assoc, 61(3), 212-217.

Pew Research Center (2019). Social Media Fact Sheet, Retrieved from: http://www.pewinternet.org/factsheets/social-networking-fact-sheet/ Accessed on: 08 January 2021.

PwC (2020). Millennials at work. Reshaping the workplace, Retrieved from: https://www.pwc.com/co/es/ publicaciones/assets/millennials-at-work.pdf Accessed on: 08 January 2021.

Schooley, S. (2020). What Is Corporate Social Responsibility?. Retrieved from: https://www.businessnewsdaily. com/4679-corporate-social-responsibility.html Accessed on: 08 January 2021.

Shetty, S., Belavadi, N., Anand, V., \& Anand, K. (2019). Brand activism and millennials: an empirical investigation into the perception of millennials towards brand activism. Problems and Perspectives in Management, 17(4), 163-175. https://doi.org/10.21511/ppm.17(4).2019.14

Smerichevskyi S., Kniazieva, T., Kolbushkin, Y., Reshetnikova I., \& Olejniczuk-Merta A. (2018). Environmental orientation of consumer behavior: motivational component. Problems and Perspectives in Management, 16(2), 424-437. https://doi.org/10.21511/ppm.16(2).2018.38

Tsimonis, G., \& Dimitriadis, S. (2014). Brand strategies in social media. Marketing Intelligence \& Planning, 32(3), 328-344. https://doi.org/10.1108/MIP-04-2013-0056

UK Green Building Council (2018). Social value in new development: An introductory guide for local authorities and development teams, Retrieved from: https://www.ukgbc.org/wp-content/uploads/2018/03/Social-Value.pdf Accessed on: 08 January 2021.

United Nations (2020). Take Action for the Sustainable Development Goals, Retrieved from: http://www.un.org/ sustainabledevelopment/sustainable-development-goals/ Accessed on: 08 January 2021.

United Nations Industrial Development Organization (2020). What is CSR?. Retrieved from: https://www.unido.org/ our-focus/advancing-economic-competitiveness/competitive-trade-capacities-and-corporateresponsibility/corporate-social-responsibility-market-integration/what-csr Accessed on: 08 January 2021.

Van Den Bergh, J., Behrer, M., \& Kerkstoel, G. (2019), How Cool Brands Stay Hot: Branding to Generation $Y$, Retrieved from: https://b-ok.cc/book/1238117/7ee5ba Accessed on: 08 January 2021.

Wiernik, B., Ones, D., \& Dilchert, S. (2013). Age and environmental sustainability: ameta-analysis. Journal of Managerial Psychology, 28(7/8), 826-856. https://doi.org/10.1108/JMP-07-2013-0221

Yusri, Y. (2020). Millenial Generation Opportunities As The Economic Driver Through The Creative Economy. In: Proceedings of the First National Seminar Universitas Sari Mulia, NS-UNISM 2019, 23rd November 2019, Banjarmasin, South Kalimantan, Indonesia. Retrieved from: https://eudl.eu/doi/10.4108/ eai.23-11-2019.2298374_Accessed on: 08 January 2021. 


\section{MILENIJALCI U STVARANJU DRUŠTVENE VREDNOSTI PREDUZEĆA}

Ovaj rad naglašava kreativne aktivnosti koje se nalaze u suštini koncepta ,,društvene vrednosti“ "koja se stvara prilikom rešavanja konkretnih socijalnih problema. Društvenu odgovornost uglavnom određuje smanjenje negativnog uticaja preduzeća na osnovu podrške i razvijanja inovativnih projekata. Analitičko poređenje kategorija „,društvena vrednost“ " $i$,društvena odgovornost" sa Ciljevima održivog razvoja otkrilo je da koncept „društvene vrednosti“ više korespondira sa strategijom održivog razvoja. Statističko proučavanje podataka iz evropskih zemalja omogućilo je da se izvede zaključak o povećanju društvene vrednosti u potrošnji, recikliranju proizvodnih resursa, korišćčenju obnovljivih izvora energije $i$ razvoju preferenci za rayvijanje sopstvenog biznisa. Na osnovu sprovedenog istraživanja, rad naglašava izuzetnu ulogu milenijalaca u modernizovanju pitanja društvenog fokusa biznisa.

Ključne reči: društvena odgovornost, društvena vrednost, strategija održivog razvoja, Generacija $Y$ 